Abstract FRI0214 - Table 1. Key Endpoints at Wk 52

\begin{tabular}{|c|c|c|c|c|c|c|}
\hline \multirow[t]{2}{*}{ Endpoints } & \multicolumn{3}{|c|}{ Sirukumab $50 \mathrm{mg} \mathrm{q} 4 \mathrm{w}$} & \multicolumn{3}{|c|}{ Sirukumab $100 \mathrm{mg} \mathrm{q} 2 \mathrm{w}$} \\
\hline & $\begin{array}{c}\text { Placebo to } \\
50 \mathrm{mg} \mathrm{q} 4 \mathrm{w}(\mathrm{n}=124)\end{array}$ & $50 \mathrm{mg} \mathrm{q} 4 \mathrm{w}(\mathrm{n}=235)$ & $\begin{array}{c}\text { Combined } \\
50 \mathrm{mg} \mathrm{q} 4 \mathrm{w}(\mathrm{n}=359)\end{array}$ & $\begin{array}{c}\text { Placebo to } \\
100 \mathrm{mg} \mathrm{q} 2 \mathrm{w}(\mathrm{n}=123)\end{array}$ & 100 mg q2w $(n=241)$ & $\begin{array}{c}\text { Combined } \\
100 \mathrm{mg} \mathrm{q2w}(\mathrm{n}=364)\end{array}$ \\
\hline ACR20 response, $\mathrm{n}(\%)$ & $68(54.8)$ & $127(54.0)$ & $195(54.3)$ & $71(57.7)$ & $145(60.2)$ & $216(59.3)$ \\
\hline ACR50 response, $\mathrm{n}(\%)$ & $41(33.1)$ & $74(31.5)$ & $115(32.0)$ & $38(30.9)$ & $77(32.0)$ & $115(31.6)$ \\
\hline HAQ-DI change from baseline, mean (SD) & $-0.30(0.55)$ & $-0.39(0.58)$ & $-0.36(0.57)$ & $-0.43(0.51)$ & $-0.43(0.60)$ & $-0.43(0.57)$ \\
\hline DAS28 (CRP) <2.6, n (\%) & $36(29.0)$ & $63(26.8)$ & 99 (27.6) & $42(34.1)$ & $71(29.5)$ & $113(31.0)$ \\
\hline \multicolumn{7}{|l|}{ SF-36 summary scores } \\
\hline PCS change from baseline, mean (SD) & $4.47(7.70)$ & $6.33(7.23)$ & $5.69(7.44)$ & $5.45(7.22)$ & $5.98(7.25)$ & $5.80(7.24)$ \\
\hline MCS change from baseline, mean (SD) & $3.64(8.48)$ & $5.19(10.84)$ & $4.65(10.10)$ & $5.60(10.62)$ & $4.46(10.45)$ & $4.85(10.51)$ \\
\hline
\end{tabular}

Janssen Research \& Development, LLC, Employee of: Janssen Research \& Development, LLC, R. Kurrasch Shareholder of: GlaxoSmithKline, Employee of: GlaxoSmithKline, P. Tak Shareholder of: GlaxoSmithKline, Employee of: GlaxoSmithKline, S. Popik Shareholder of: Janssen Research \& Development, LLC, Employee of: Janssen Research \& Development, LLC

DOI: 10.1136/annrheumdis-2017-eular.6486

\section{FRI0215 COMPARATIVE EFFICACY AND RETENTION RATE OF TOCILIZUMAB AND TNF INHIBITORS USED IN COMBINATION WITH METHOTREXATE AS FIRST-LINE BIOLOGIC THERAPY IN RHEUMATOID ARTHRITIS: DATA FROM A MULTICENTRE OBSERVATIONAL REGISTRY}

E.G. Favalli ${ }^{1}$, M. Biggioggero ${ }^{1}$, P. Sarzi Puttini ${ }^{2}$, F. Atzeni ${ }^{2}$, E. Fusaro ${ }^{3}$, V. Grosso ${ }^{4}$, R. Pellerito ${ }^{5}$, R. Gorla ${ }^{6}$, C. Bazzani ${ }^{6}$, A. Marchesoni ${ }^{1}$, R. Caporali ${ }^{4}$. ${ }^{1}$ Department of Rheumatology, Gaetano Pini Institute; ${ }^{2}$ Rheumatology Unit, University Hospital L. Sacco, Milano, ${ }^{3}$ Rheumatology, Azienda Ospedaliera Universitaria Città; della Salute e della Scienza, Torino: ${ }^{4}$ Rheumatology, University of Pavia, IRCCS Policlinico San Matteo Foundation, Pavia; ${ }^{5}$ Rheumatology, Ospedale Mauriziano, Torino; ${ }^{6}$ Rheumatology Unit, Spedali Civili, Brescia, Italy

Background: Despite a demonstrated superiority of interleukin- 6 over tumour necrosis factor (TNF) blockade when used as monotherapy, the choice of the first biologic agent (bDMARD) for treating rheumatoid arthritis (RA) in combination with methotrexate (MTX) is still a challenge for rheumatologist.

Objectives: To retrospectively evaluate in a multicentre observational cohort of Northern Italy (the LORHEN registry) the 6- and 12-month comparative drug survival and remission rate of tocilizumab (TCZ) and TNF inhibitors (TNFis) used as first bDMARD in combination with MTX.

Methods: All RA patients treated with TCZ or a TNFi as first-line bDMARD with at least 12-month follow-up were selected from the LORHEN registry. The analysis was limited to the period from January 2009 to May 2016 and to patients receiving either TCZ or TNFi in combination with MTX, excluding bDMARD monotherapy. Six- and 12-month clinical remission rate was defined as achievement of disease activity score 28 calculated by using erythrosedimentation rate (DAS28-ESR) $<2$.6. Drug persistence was calculated by Kaplan-Meier method. The comparison between treatment subgroups was performed by a chi-square test for remission data and by a log-rank test for drug survival. Moreover, DAS28-ESR remission rate has been corrected for drug discontinuation by using the LUNDEX formula (1).

Results: The overall study population included 591 patients (female $77.3 \%$, mean age [ \pm standard deviation, SD] $54.2 \pm 13.2$ years, mean disease duration $[ \pm S D]$ $7.4 \pm 7.7$ years, positive rheumatoid factor $67.5 \%$, positive anti-citrullinated peptide antibodies $77.6 \%$, mean baseline DAS28-ESR 5.1 1.2$)$ treated with TCZ $(n=61)$ or TNFis ( $n=530$; infliximab 43 , adalimumab 163, etanercept 195 , golimumab 60 , certolizumab pegol 69). Baseline characteristics were similar in the two groups, with the exception of mean age (TCZ 58.2 vs TNFis 53.7 years; $p=0.021$ ). No significant differences $(p=0.361)$ emerged in the 6 - (TCZ $88 \%$ vs TNFis $84.3 \%$; $p=0.752$ ) and 12 -month (TCZ $76.4 \%$ vs TNFis $71.5 \%$;) retention rate. Clinical remission was achieved in overall $35.7 \%$ patients at 6 months (TCZ 59\% vs TNFis $33 \% ; p<0.001$ ) and in $36.8 \%$ patients at 12 months (TCZ $58.8 \%$ vs TNFis $34.5 \%$; $\mathrm{p}<0.001)$. Similar trends were observed after correction by LUNDEX formula at 6 (TCZ $51.9 \%$ vs TNFis $27.8 \%$ ) and 12 months (TCZ $44.9 \%$ vs TNFis $24.6 \%$ ).

Conclusions: Despite a similar 1-year retention rate, the proportion of patients achieving DAS28-ESR remission was significantly higher in TCZ+MTX treated group compared with TNFis+MTX, suggesting a deeper clinical response in patients receiving IL 6 blockade.

References:

[1] Kristensen LE, et al. Arthritis Rheum 2006:54:600-6.

Disclosure of Interest: None declared

DOI: 10.1136/annrheumdis-2017-eular.4771
FRI0216 RESULTS OF A LONGITUDINAL REVIEW OF PULMONARY FUNCTION AND SAFETY DATA IN A PHASE IIB CLINICAL PROGRAMME TESTING GRANULOCYTE-MACROPHAGE COLONY-STIMULATING FACTOR (GM-CSF) RECEPTOR ANTAGONIST MAVRILIMUMAB FOR TREATMENT OF RHEUMATOID ARTHRITIS (RA)

G. Burmester ${ }^{1}$, M.A. Michaels ${ }^{2}$, D. Close ${ }^{3}$, A. Godwood ${ }^{3}$, K. Middleton ${ }^{3}$, P. Miranda ${ }^{4}$, J. Vencovský ${ }^{5}$, J. Kremer ${ }^{6}$, I.B. McInnes ${ }^{7}$, M. Albulescu^ ${ }^{3}$ M. Weinblatt ${ }^{\wedge} 8{ }^{1}$ Charité - University Medicine Berlin, Berlin, Germany; ${ }^{2}$ Medlmmune, Gaithersburg, United States; ${ }^{3}$ Medlmmune, Cambridge, United Kingdom; ${ }^{4}$ Centro de Estudios Reumatológicos, Santiago, Chile; ${ }^{5}$ Institute of Rheumatology, Prague, Czech Republic; ${ }^{6}$ The Albany Medical College, Albany, United States; ${ }^{7}$ University of Glasgow, Glasgow, United Kingdom; ${ }^{8}$ Brigham and Women's Hospital, Boston, United States

Background: RA is associated with pulmonary comorbidity and lung function decline over time, but longitudinal assessment of pulmonary abnormalities in the context of RA treatment needs further characterisation. Mavrilimumab, an investigational human monoclonal antibody, inhibits GM-CSF by binding to the GM-CSF receptor $\alpha$ subunit.

Objectives: To investigate the pulmonary safety of mavrilimumab because of the theoretical risk of inhibiting alveolar macrophage function and causing pulmonary alveolar proteinosis (PAP).

Methods: Pulmonary monitoring included standardised serial pulmonary function testing (spirometry and diffusing capacity of lung carbon monoxide [DLCO]), chest X-rays, assessments of dyspnoea and pulmonary adverse events (AEs) in two randomised, double-blind studies (NCT01706926; NCT01715896) where patients (pts) with moderate to severe RA received mavrilimumab 30,100 or $150 \mathrm{mg}$ every other week (eow), or placebo and mavrilimumab $100 \mathrm{mg}$ eow or golimumab $50 \mathrm{mg}$ every 4 weeks, respectively. Eligible pts transferred to the open-label extension study (NCT01712399) and received mavrilimumab $100 \mathrm{mg}$ eow. All studies excluded pts with clinically significant uncontrolled pulmonary disease. An Independent Pulmonary Evaluation Committee (IPEC), blinded to treatment, adjudicated pulmonary AEs and lung function abnormalities.

Results: Mavrilimumab was received by 442 pts with cumulative safety data exposure of approximately 900 pt-yrs and a median (range) exposure time of $2.5(0.1-3.3)$ yrs. Baseline (BL) characteristics are shown (Table). Mean dyspnoea (Table), forced expiratory volume in 1 second ( $\left.F E V_{1}\right)$, forced vital capacity (FVC) and DLCO were mostly maintained within $5 \%$ of $B L$ values for pts treated with mavrilimumab during the clinical programme. Clinically relevant decreases in predicted $\mathrm{FEV}_{1}$ and FVC ( $>20 \%$ from $\mathrm{BL}$ and $<80 \%$ predicted) were demonstrated by $\leq 6.2 \%$ of pts at any visit (Table); decreases were mostly transient with no apparent trends. Overall, 83 pts (9.24/100 pt-yrs) reported $\geq 1$ pulmonary AE; bronchitis was reported most frequently (34 pts [3.78/100 pt-yrs]); one $\mathrm{AE}$ was considered serious and treatment-related (acute bronchitis). The reported pulmonary $\mathrm{AE}$ rate was generally stable over time. No suspected or confirmed PAP cases were found by IPEC and no pulmonary-related deaths were reported.

Conclusions: We believe this is the most comprehensive longitudinal study of pulmonary function in a clinical RA programme. The BL pulmonary function profile indicates that this is not a normal population from a pulmonary health perspective. Mavrilimumab was not associated with substantial decline in pulmonary function or PAP in pts treated up to 3.3 years; its acceptable safety profile advocates initiation of Phase III studies with mavrilimumab. Further studies are now required to fully characterise pulmonary function over time in RA.

Acknowledgements: Funded by Medlmmune. Medical writing support: R Plant, QXV Comms, an Ashfield company, funded by Medlmmune.

^Senior author.

Disclosure of Interest: G. Burmester Consultant for: Medlmmune, M. Michaels Employee of: Medlmmune, D. Close Employee of: Medlmmune, A. Godwood Shareholder of: AstraZeneca, Employee of: Medlmmune, K. Middleton Employee of: Medlmmune (contracted employment at time of study), P. Miranda Grant/research support from: Amgen, Medimmune, Janssen, Pfizer, Celltrion, Abbott, Sanofi, Actelion, Merck \& Co, Boehringer, BMS, Consultant for: Pfizer [Etanecept: Fee less than USD5000], J. Vencovský Consultant for: Pfizer, Elli Lilly, MSD, Novartis, Speakers bureau: Biogen, Pfizer, MSD, Abbvie, Novartis, Boehringer, UCB, BMS, J. Kremer Shareholder of: Corrona, Grant/research support from: Abbvie, Amgen, Genentech, Lilly, Pfizer, Consultant for: Abbvie, Amgen, BMS, Genentech, Lilly, Pfizer, Employee of: Corrona, I. McInnes Grant/research support from: Medlmmune [The University of Glasgow is a charity registered in 